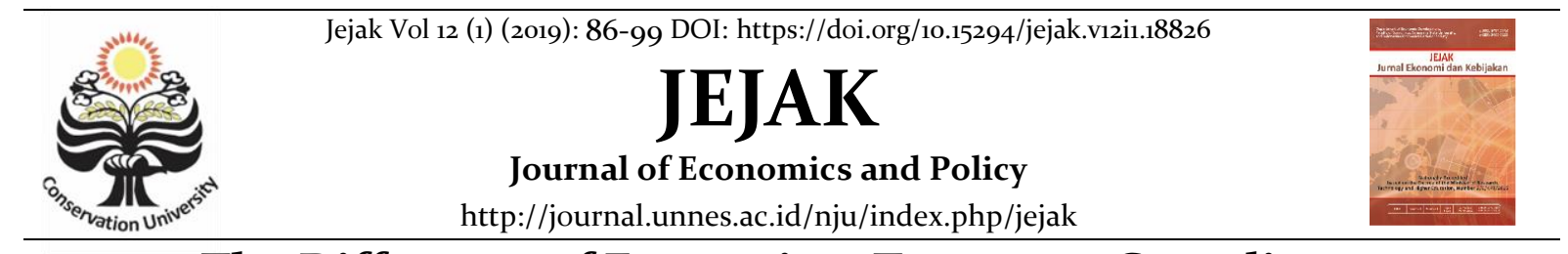

\title{
The Difference of Enterprises Taxpayers Compliance after Tax Amnesty
}

\author{
Dona Fitria $^{1}$, Agus Abdillah ${ }^{\bowtie 2}$, Hendro Prasetyono³, Ismail Dwi Cahyo', Burhanudin 5 \\ ${ }^{1234}$ Department of Education Economic, Indraprasta PGRI University \\ ${ }^{5}$ Department of Conseling and Guidence, Indraprasta PGRI University
}

Permalink/DOI: https://doi.org/10.15294/jejak.v12i1.18826

Received: October 2018; Accepted: January 2019; Published: March 2019

\begin{abstract}
The purpose of this study was to determine and analyze the compliance of enterprises taxpayers before and after the tax amnesty was applied in KPP Pratama South Jakarta. The research location was at KPP Pratama Jakarta Cilandak, KPP Pratama Jakarta Pancoran, KPP Pratama Jakarta Mampang, and KPP Pratama Jakarta Pasar Minggu. Data collection with documentation techniques, namely secondary data collection. Taxpayer's compliance data for 2015, which is SPT as of March 2016, is assumed to be data before tax amnesty. While the 2016 taxpayer's compliance data which is SPT as of March 2017 is assumed to be the data of the tax amnesty validity period. The data analysis technique in this study uses the SPT taxpayer compliance ratio 2016 2017. Statistical tests using Paried Sample t-Test. The results of the study showed that the amount of enterprises taxpayer compliance submitting timely Annual Tax Returns increased by $10.60 \%$ from $13.40 \%$ to $24.00 \%$. Furthermore, the taxpayer's compliance ratio that did not submit the Annual Tax Return decreased by 3.90\%, namely in 2016 amounted to $76.92 \%$ to 73.02\% in 2017. The Paired Sample t-Test has different Enterprises Taxpayer's compliance before and after the enactment of tax amnesty.
\end{abstract}

Key words : Taxpayer's compliance, Tax Amnesty, Paired sample t-test

How to Cite: Fitria, D., Abdillah, A., Prasetyono, H., Cahyo, I., \& Burhanudin, B. (2019). The Difference of Enterprises Taxpayers Compliance after Tax Amnesty. JEJAK: Jurnal Ekonomi dan Kebijakan, 12(1), 86-99. doi:https://doi.org/10.15294/jejak.v12i1.18826 


\section{INTRODUCTION}

Tax is the country's main source of income used to finance government spending and development. The increasing amount of government expenditure in the context of state financing demands an increase in state revenues, one of which comes from tax revenues. In order to increase tax revenue, the government carried out a major reform in the field of taxation in 1983 which originally adopted an official assestment system where the responsibility of the tax collection system rested with tax officials (tax authorities) into a self-assessment system. Self assestment system is a tax collection system where taxpayers are given the trust to register themselves, calculate, deposit and report on themselves the amount of tax payable in accordance with the provisions of legislation Tax tax is the country's main source of income used to finance government spending and development. The increasing amount of government expenditure in the context of state financing demands an increase in state revenues, one of which comes from tax revenues.

In order to increase tax revenue, the government carried out a major reform in the field of taxation in 1983 which originally adopted an official assestment system where the responsibility of the tax collection system rested with tax officials (tax authorities) into a self-assessment system. Self assestment system is a tax collection system where taxpayers are given the trust to register themselves, calculate, deposit and report on themselves the amount of tax payable in accordance with the provisions of tax legislation (Pranadata, 2014). The problem that often occurs is that there are still many people who do not want to fulfill their tax obligations, in other words there are still many tax arrears. Taxation is at the heart of citizens' relationship with the State (Kovárník, et.al., 2014). The level of individual taxpayer compliance to fulfill tax payment obligations in Indonesia is still quite low. This can be seen from the low tax ratio to GDP (tax ratio) which is in the range of $11 \%$ of data in 2016 . This ratio is clearly still relatively low compared to the world average or OECD countries (both around 14\%) Indonesia can still be considered undertaxing conditions. With the population being ranked $5^{\text {th }}$ largest in the world, Indonesia should have a lot of tax potential that can be explored (Aryobimo, 2012). Still not optimal tax collection causes Indonesia's tax ratio to be lower when compared to countries in the Southeast Asia region. According to Mardiasmo (2014), tax payments from private taxpayers have been too low. Especially, taxpayers are from nonemployees or have their own jobs including professional businesses. This shows that individual taxpayers such as entrepreneurs and professions have not fulfilled their tax obligations properly. The low level of tax compliance is an indicator of low tax absorption by the government.

Until now the government is trying to improve infrastructure development, with consideration that good infrastructure development will provide a large and sustainable multiplier effect on economy. Infrastructure development is also expected to trigger the acceleration of equitable development in all parts of Indonesia. This can be seen from the seriousness of the government that actively promotes infrastructure development in various fields, both land, sea and air infrastructure such as the construction of toll roads, trans roads, bridges, ports, sea tolls, airports, and others. The incessant infrastructure development certainly requires huge funds. In 2016, the infrastructure budget in the 2016 State Budget (APBN) reached Rp. 313.5 trillion. This figure increased significantly compared to the Revised State Budget (APBN-P) in 2015 which was only 
Rp.290.3 trillion. This is a problem because the source of state revenue of around 75 percent comes from the tax sector and at the same time its realization has never been achieved, except in 2011, even the trend has decreased.

The Indonesian government has conducted various ways to increase state revenues from the tax sector. Starting from the policy of every state official always reports wealth, socialization to the public up to press coverage or advertisements of celebrities paying taxes. Advertisements or news coverage of celebrities or famous figures who obey paying taxes have successfully influenced the behavior of German citizens (Garz \& Pagels, 2018). But this was not successful in Indonesia.

Awareness to pay taxes that are low in diction becomes one of the reasons for this. Tax knowledge and tax complexity are viewed as contributing factors towards non-compliance behavior among taxpayers (Saad, 2014).

In various research results, Supadmi (2010) said that taxpayer compliance can be identified with criteria, among others; taxpayers understand or try to understand all the provisions of taxation laws and regulations, complete tax forms completely and clearly, calculate the amount of tax owed correctly, pay taxes payable on time. While Muliari and Setiawan (2010) explained that the criteria of taxpayers compliant according to the Minister of Finance Decree No.544 / KMK.04 / 2000 compliant taxpayers are as follows; on time to submit tax returns for all types of taxes in the past two years, do not have tax arrears for all types of taxes, unless it has obtained a license to pay in installments or postpone tax payments, it has never been sentenced for committing a crime in taxation within 10 years lastly, and in the last two years carrying out bookkeeping and in the case of the taxpayer having conducted an examination, correction of the last examination for each type of tax payable is at most five
percent.Responding to the problem of noncompliance taxpayers, according to Cahyonowati (2011), personal taxpayer compliance can be improved through a mechanism of fines and tax audits (enforced economic deterrence variables) (enforced tax compliance). But based on research by Kogler et al (2013) and Kircheler et al (2008), the mechanism of fines and tax audits becomes less effective in increasing voluntary compliance if done in the long term. Designing tax policies that are effective in curbing tax evasion and maximize state revenues requires a rigorous understanding of taxpayer behavior (Goumagias, Varsakelis \& Assael, 2018).

The problem of taxpayer compliance is a very serious problem in Indonesia, because if the Taxpayer does not comply then the desire to do avoidance, circumvention and tax disbursement will arise, and in the end it will be detrimental to the country due to reduced tax revenue which is a country's main income. There are two factors that influence taxpayer compliance namely internal factors and external factors. Internal factors are factors that come from self. Taxpayers themselves, while external factors are factors that come from outside the taxpayer.

Attribution theory states that a person in determining the level of compliance or not an individual taxpayer in fulfilling his tax obligations is influenced by internal and external factors. Internal factors that affect the level of compliance of individual taxpayers include the level of understanding of taxpayers and awareness of taxpayers. Unlike internal factors, external factors that influence the level of compliance of individual taxpayers include taxation policies and tax sanctions. Tax has several functions, namely 1) The function of the budgetair or what is also called the revenue function and the main source of state cash, is the tax function as a source of funds intended for financing expenditure - government expenditure. 
An example is the inclusion of taxes in the APBN as domestic revenues. 2) Regular function or often referred to as the function of regulating / regulating economic activities. Tax has a role as a tool to regulate or implement policies in the social and economic fields.

According to Handayani and Laily (2017), despite sanctions, there are still many taxpayers who are negligent to pay their obligations. According to Swistak (2015), it is necessary to think carefully in making tax sanctions so that tax evasion does not occur by taxpayers. Taxpayer awareness is the willingness that arises from within the taxpayer to pay his tax obligations sincerely without coercion even though the taxpayer cannot directly enjoy the tax he pays. Then the awareness of taxpayers needs to be raised on the tax function as state funding.

One of the real efforts made by the Indonesian government is the implementation of a tax amnesty program. Many conditions are behind the government's decision to run a tax amnesty program. These conditions include not achieving the tax collection targets in 2015, the level of taxpayer compliance that is still low, the need for a more credible new taxpayer database and the existence of Automatic Exchange Information between countries in the world that will be implemented in 2018 .

Giving tax amnesty is a government effort to attract public funds this is parking in other countries' banks. "Tax amnesty is given to those who so far not paying properly, "said Deputy Finance Minister Mardiasmo at the sidelines of the XII Congress of the Indonesian Institute of Accountants, in Jakarta, Thursday (18/12) thus, this policy still needs to be harmonized with other law enforcement agencies and discussed with the House of Representatives (DPR). This is related to the parties considered worthy of forgiveness. For example, he said, is it aviolator tax crimes may get forgiveness if it is not related to corruption "It must be discussed in the cabinet, police and law enforcement meetings," he said. Mardiasmo optimistic, this policy will increase tax revenues. Government in 2008 ever do sunset policy, which is the elimination of tax administration sanctions in the form of interest. At that time, the government managed to raise funds of around Rp 5.5 trillion from the program. In Law No. 11 of 2016, Article 1 (1) what is meant by tax amnesty is the elimination of taxes that ought to be owed, not subject to tax administration sanctions and criminal sanctions in the field of taxation by disclosing property and paying ransom. In Article 1 (3), the assets referred to are additional accumulations of economic capability in the form of all tangible and intangible assets, both movable and immovable, whether used for business or not for business, which are inside and / or outside the region The Unitary State of the Republic of Indonesia. Whereas in Article 1 (7), the ransom is the amount of money paid to the state treasury to get Tax Amnesty.

Tax Amnesty in 2016 is divided into several periods, namely: the first period starts on July 1 , 2016 and will expire on September 30, 2016 while the Tax Amnesty period for the second period begins on October 1, 2016 and will expire on December 31, 2016, while the third period starting January 1, 2017 until March 31, 2017. Taxation policies that have been carried out by Indonesia before 2016 are among others the tax amnesty program in 1964 and 1984, and the sunset policy program which is considered the mini version of the tax amnesty program in 2008 .

In essence, the implementation of tax amnesty and sunset policy even though psychologically it is not in favor of taxpayers who have been paying taxes. Even if the policy is applied in a country, there must be an in-depth study of the characteristics of taxpayers in a country because the characteristics of the taxpayer of course vary. For many countries, tax amnesty is often used as a tool to collect tax 
revenues (tax revenue) quickly in a relatively short period of time.

The Russian Federation during its main transition period of the 1990s and analyzes the impact of these amnesties on tax collections. The result is seemed unlikely to have had significant and demonstrable positive - or negative impacts on the revenues of the Russian Federation, a conclusion that calls into question their usefulness as a policy instrument (Alm, Vasquez and Wallace, 2009).The results of these studies are supported by research Bose \&Jetter (2012) We show that tax evaders can respond to a tax amnesty, even if enforcement activities do not change, if it is timed to coincide with liberalization and rising incomes.

The tax amnesty program is implemented because of the increasingly severe tax avoidance efforts. This policy can benefit from the acquisition of funds, especially the return of funds deposited abroad, and this policy has longterm weaknesses that can result in a decline in voluntary compliance from compliant taxpayers, if the tax amnesty is carried out with improper programs .Finding research byBayer, Oberhofer\& Winner (2015) In line with the theoretical model, our empirical findings suggest that the likelihood of amnesties is mainly driven by a government's fiscal requirements and the taxpayers' expectations on future amnesties. Some tax experts argue that tax amnesty is an effective way to increase tax compliance. Even so, there are also concerns that tax amnesty can weaken taxpayer compliance, especially if people hope that tax amnesty might come again in the future (Andreoni in Darussalam et al, 2014).

\section{RESEARCH METHOD}

This study uses descriptive qualitative research, which is research conducted on the condition of natural objects without manipulation, where the researcher as a key instrument, Sugiyono (2010: 14). This research focuses more on field research, because this research is done by directly relating to the object of research. This research was carried out at KPP Pratama Jakarta Cilandak, KPP Pratama Jakarta Pancoran, KPP Pratama Jakarta Mampang, and KPP Pratama Jakarta Pasar Minggu. Subjects in this study are individual taxpayers who have a business. The object of this research is Individual Taxpayer's Compliance after the enactment of the Tax Amnesty policy. The data in this study were collected with documentation and interview techniques.

The data needed includes the amount of Taxpayer Enterprises data that submits Annual SPT and the sum of Taxpayer registered in KPP Pratama Jakarta Cilandak, KPP Pratama Jakarta Pancoran, KPP Pratama Jakarta Mampang, and KPP Pratama Jakarta Pasar Minggu 2016 until 2017. Researchers use unstructured interviews, the researcher does not use interview guidelines or systematically, the research guidelines are in the form of broad outlines of Taxpayer's Compliance issues, tax amnesty policy issues, and Annual Tax Returns. Data analysis techniques using compliance ratio analysis and analysis of different test of taxpayer's compliance with Paired Sample t-test. For compliance ratio analysis, among others; mandatory compliance ratio on time, the ratio of taxpayer compliance is not timely, and the ratio of taxpayer compliance does not submit annual tax returns both in 2016 and 2017 can be calculated by the following formula:

$$
\frac{\text { Taxpayer annual SPT on time }}{\text { Taxpayer registered annual SPT }} \times 100 \% \text {.... }
$$

The Regulation of the Minister of Finance of the Republic of Indonesia No: 74 / PMK.03 / 2012 regulates that Taxpayers are called Taxpayers compliant if they fulfill several 
requirements, one of which is timely in submitting an SPT. Taxpayers who are compliant are taxpayers who carry out their obligations in accordance with the provisions of taxation laws and regulations.

$$
\frac{\text { Taxpayer annual SPT late }}{\text { Taxpayer registered annual SPT }} \times 100 \% \ldots . .(2)
$$

The amount of Annual Taxpayer SPT used in this calculation is the Taxpayer Annual SPT which is not timely, which is submitted more than three months after the end of the Tax Year.

$$
\frac{\text { Taxpayer annual SPT not convey }}{\text { Taxpayer registered annual SPT }} \text { x } 100 \ldots . . .(3)
$$

The number of Taxpayers who do not submit Annual Tax Returns in this calculation is the difference between the number of registered Taxpayers who are obliged to submit Annual Tax Returns and the total number of Taxpayer Annual SPT receipts for one year.

Whereas for the analysis of different test of taxpayer's compliance before and after the tax amnesty policy, the normality test is first determined. The samples used in different tests are interconnected and if the results of the normality test show that the sample is normally distributed, the difference test used in this study is the paramed test (Paired sample t-test). But if the sample is not normally distributed, the different test that will be used in this study is a non-parametic test (Wilcoxon Signed Rank Test).

\section{RESULTS AND DISCUSSION}

Based on the results of documentation studies that have been carried out at KPP Pratama Jakarta Cilandak, KPP Pratama Jakarta Mampang, KPP Pratama Jakarta Pancoran, and KPP Pratama Jakarta Pasar
Minggu, a summary table of Enterprises Taxpayer that submit Annual Tax Returns on time, not on time and not report in the table 1.

Information regarding changes in Annual Tax Returns receipts between 2016 and 2017 can also be presented in the following diagram:

Table 1. Sum of Enterprises Taxpayer that submit Annual Tax Return in 2016 and 2017

\begin{tabular}{lcc}
\hline Month & \multicolumn{2}{c}{ Year } \\
\hline January & 2016 & $\mathbf{2 0 1 7}$ \\
February & 219 & 53 \\
March & 4,504 & 287 \\
April & 634 & 5,323 \\
May & 85 & $\mathbf{2 . 6 3 1}$ \\
June & 55 & 151 \\
July & 29 & 133 \\
August & 113 & 95 \\
September & 655 & 104 \\
October & 169 & 59 \\
November & 112 & 57 \\
December & 354 & 51 \\
More than 31 Dec & $\mathbf{1 , 2 2 2}$ & 46 \\
Total & 8,180 & 337 \\
\hline Source: Data & 9,327 \\
\hline
\end{tabular}

Source: Data and Information Processing Unit of KPP Pratama South Jakarta 2018

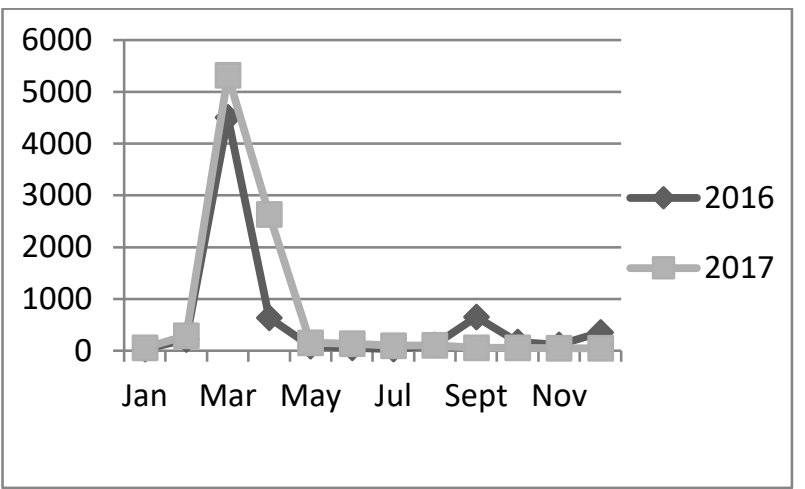

Figure 1. Sum of Enterprises Taxpayer that submit Annual Tax Return in 2016 and 2017 Source : Data processed, 2018

In figure 1. Above, we can observe that taxpayers submitting Annual Tax Returns tend to increase sharply in March. This is because the Taxation Law stipulates that taxpayers are said to be "Obedient" if the taxpayer pays tax 
no later than March 31. The exception is that when the tax amnesty is implemented, taxpayers are said to be obedient if they submit Annual Tax Returns no later than April 30.

Based on table 2 above, we can know that overall number taxpayers at KPP Pratama in South Jakarta has been reduced. However, the number of taxpayers who are on time to pay taxes has increased sharply.

Table 2. Sum of Enterprises Taxpayer Delivering Annual Tax Returns on Time, Not On Time and Not Reporting

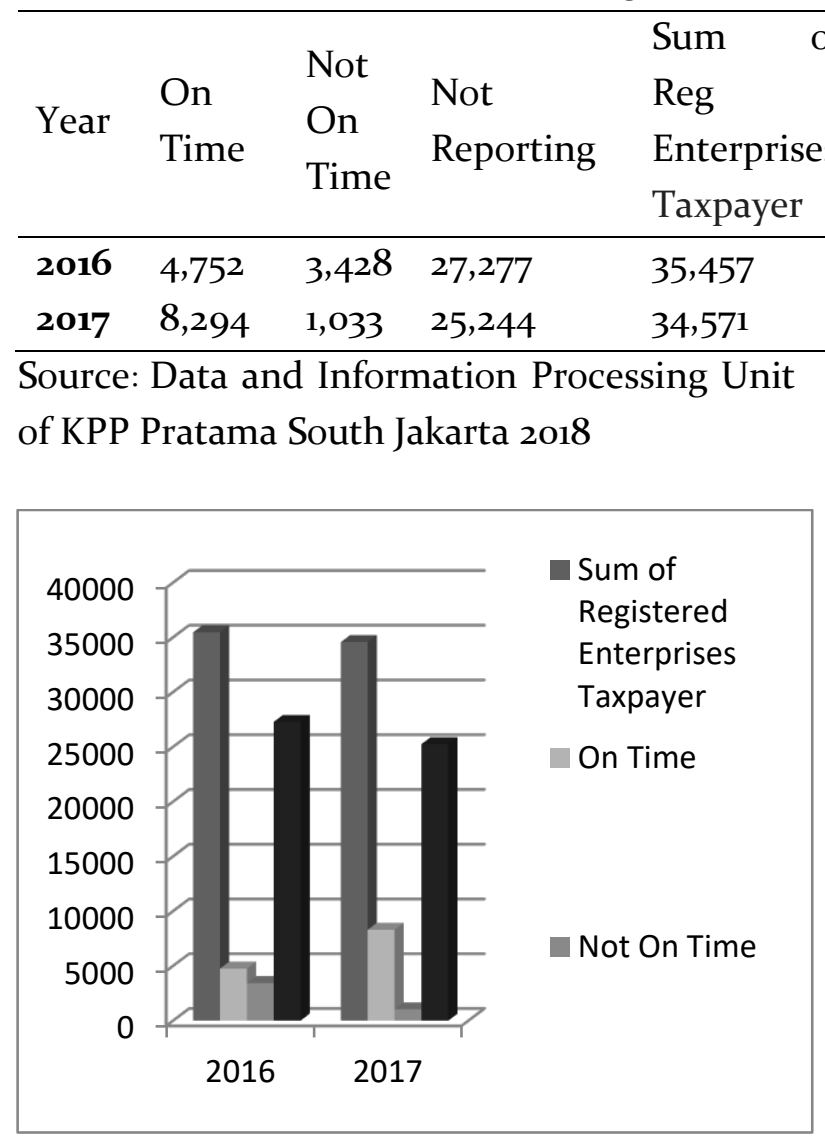

Figure 2. Sum of Enterprises Taxpayer Delivering Annual Tax Returns on Time, Not On Time and Not Reporting Source : Data processed 2018

Then for taxpayers who pay late, before and after the tax amnesty significantly decreases. This can be interpreted that the implementation of the tax amnesty is quite significant in increasing the level of tax compliance.Taxpayer's Compliance Ratio Before Tax Amnesty Enactment in 2016, The results of the calculation of the following table shows that the taxpayer compliance ratio that submits the SPT on time undergoes a change. The amount of Enterprises Taxpayer on time before the enactment of tax amnesty 2016 is 4,752 with the taxpayer's compliance ratio of $13.40 \%$. Taxpayer's Compliance Ratio is the highest at $12.70 \%$ in March. While the lowest compliance ratio is only $0.08 \%$ in January 2016.

Table 3. Sum of Enterprises Taxpayer Delivering Annual Tax Returns On Time in 2016

\begin{tabular}{lll}
\hline Month & $\begin{array}{l}\text { Taxpayer } \\
\text { On Time }\end{array}$ & Ratio (\%) \\
\hline January & 29 & 0.082 \\
February & 219 & 0.62 \\
March & 4,504 & 12.70 \\
Total & 4,752 & 13.40 \\
\hline
\end{tabular}

Source: Processed data 2018

Table 4. Sum of Enterprises Taxpayer Delivering Annual Tax Returns Not On Time in 2016

\begin{tabular}{lll}
\hline Month & $\begin{array}{l}\text { Taxpayer } \\
\text { On Time }\end{array}$ & Not \\
\hline April & 634 & 1.79 \\
May & 85 & 0.24 \\
June & 55 & 0.16 \\
July & 29 & 0.082 \\
August & 113 & 0.32 \\
September & 655 & 1.86 \\
October & 169 & 0.47 \\
November & 112 & 0.32 \\
December & 1,576 & 4.44 \\
Total & 3,428 & 9,68 \\
\hline
\end{tabular}

Source: Processed data 2018

While the calculation results in Table 4 . show that the taxpayer's compliance ratio that 
does not timely deliver Annual Tax Returns in 2016 is always changing. The amount of Enterprises Taxpayer is not on time before the 3,428 tax amnesty applies with the taxpayer's non-compliance ratio of $9.68 \%$. The highest taxpayer's non-compliance ratio was $4.44 \%$ in December 2016. While the lowest noncompliance ratio is only $0.16 \%$ in June 2016 .

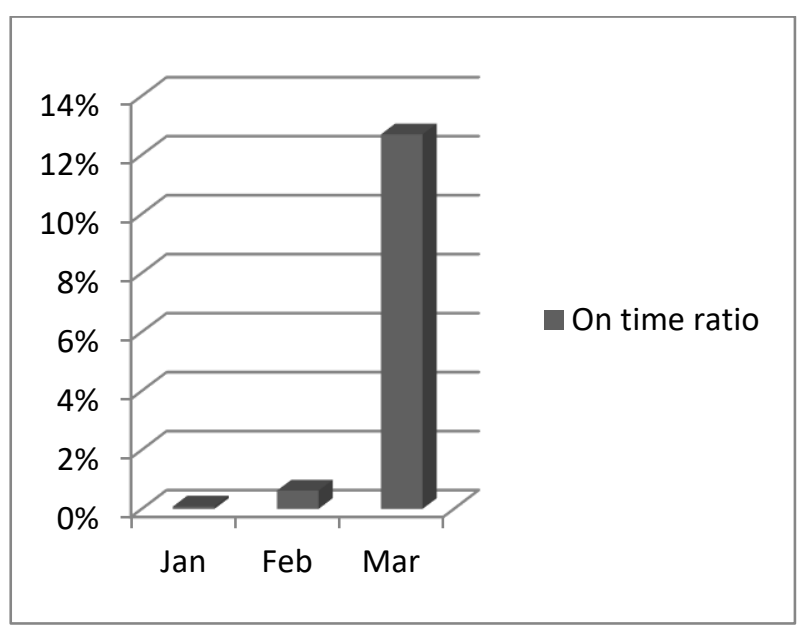

Figure 3. Sum of Enterprises Taxpayer

Delivering Annual Tax Returns On Time in 2016 Source: Processed data 2018

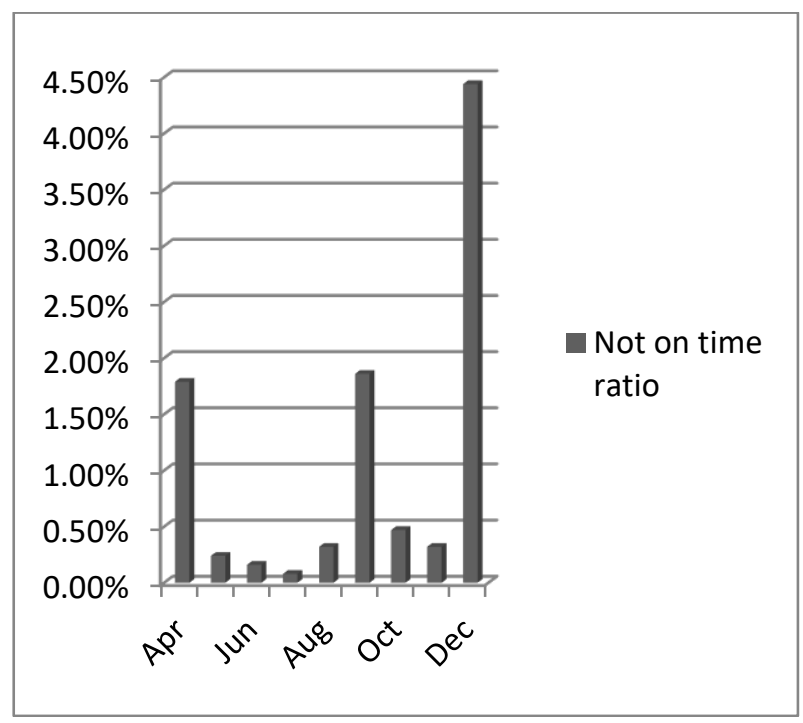

Figure 4. Sum of Enterprises Taxpayer Delivering Annual Tax Returns Not On Time in 2016

Source: Processed data 2018

Furthermore, the results of calculations based on table 5 . below show that the number of Enterprises Taxpayer that did not submit Annual Tax Returns was 27,277 with the taxpayer's compliance ratio of $76.92 \%$.

Table 5. Sum of Enterprises Taxpayer Didn't Deliver Annual Tax Returns in 2016

\begin{tabular}{llll}
\hline Year & $\begin{array}{l}\text { Taxpayer } \\
\text { Registered }\end{array}$ & $\begin{array}{l}\text { Taxpayer } \\
\text { Didn't } \\
\text { Deliver }\end{array}$ & $\begin{array}{l}\text { Ratio } \\
(\%)\end{array}$ \\
\hline 2016 & 35,457 & $\mathbf{2 7 , 2 7 7}$ & 76.92 \\
Total & 35,457 & 27,277 & 76.92 \\
\hline
\end{tabular}

Source: Processed data 2018

Taxpayer's Compliance Ratio After Tax Amnesty Enactment in 2017, Based on calculation results of the following table bhows that the taxpayer compliance ratio that submits the SPT on time undergoes a change. The amount of Enterprises Taxpayer on time after the enactment of tax amnesty 2017 is 8,294 with the taxpayer compliance ratio of 24.00\%. Taxpayer's Compliance Ratio is the highest at $\mathbf{1 5 . 4 0 \%}$ in March. While the lowest compliance ratio is only $0.15 \%$ in January 2017.

The exception is that when the tax amnesty is implemented, taxpayers are said to be obedient if they submit Annual Tax Returns no later than April 30.

Table 6. Sum of Enterprises Taxpayer Delivering Annual Tax Returns On Time in 2017

\begin{tabular}{lcc}
\hline Month & $\begin{array}{c}\text { Taxpayer } \\
\text { On Time }\end{array}$ & Ratio (\%) \\
\hline January & 53 & 0.15 \\
February & 287 & 0.84 \\
March & 5,323 & 15.40 \\
April & 2,631 & 7.61 \\
Total & 8,294 & 24.00 \\
\hline
\end{tabular}

Source: Processed data 2018 
Furthermore, the calculation results in Table 7. below show that the taxpayer's compliance ratio that does not timely deliverAnnual Tax Returns in 2017 is always changing.

The amount of Enterprises Taxpayer is not on time before the 1,033 tax amnesty Furthermore, the calculation results in Table 7. below show that the taxpayer's compliance ratio that does not timely deliver Annual Tax Returns in 2017 is always changing. The amount of Enterprises Taxpayer is not on time before the 1,033 tax amnesty applies with the Taxpayer's non-compliance ratio of $2.98 \%$. The highest taxpayer's non-compliance ratio was 1.11\% in December. While the lowest noncompliance ratio is only $0.15 \%$ in November 2017.

Table 7. Sum of Enterprises Taxpayer Delivering Annual Tax Returns Not On Time

\begin{tabular}{lll} 
& \multicolumn{2}{c}{ in 2017} \\
\hline Month & $\begin{array}{l}\text { Taxpayer } \\
\text { On Time }\end{array}$ & Not \\
& 151 & 0.43 \\
\hline May & 133 & 0.38 \\
June & 95 & 0.27 \\
July & 104 & 0.31 \\
August & 59 & 0.17 \\
September & 57 & 0.16 \\
October & 57 \\
November & 51 & 0.15 \\
December & 383 & 1,11 \\
Total & 1,033 & 2.98
\end{tabular}

Source: Processed data 2018

While the results of calculations based on table 8 . below show that the number of Enterprises Taxpayer that did not submit Annual Tax Returns was 25,244 with the taxpayer's compliance ratio of $73.02 \%$.

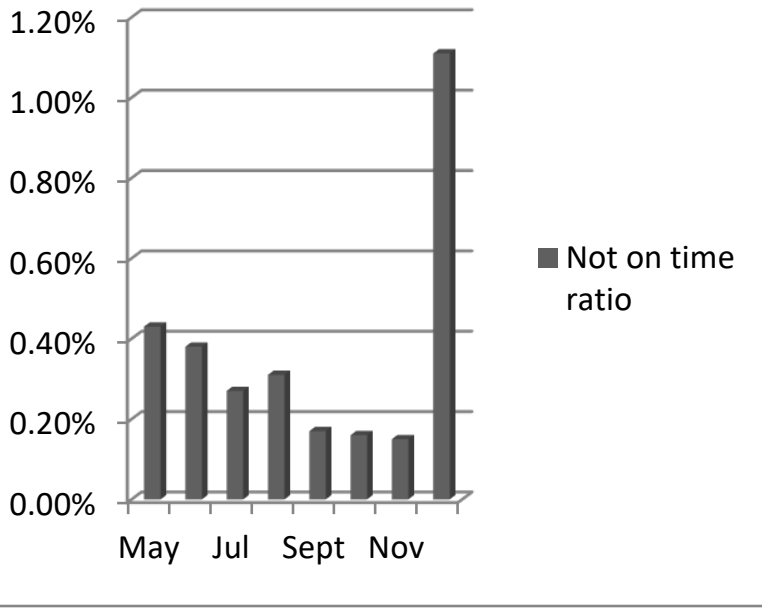

Figure 4. Sum of Enterprises Taxpayer Delivering Annual Tax Returns Not On Time in 2016

Source: Processed data 2018

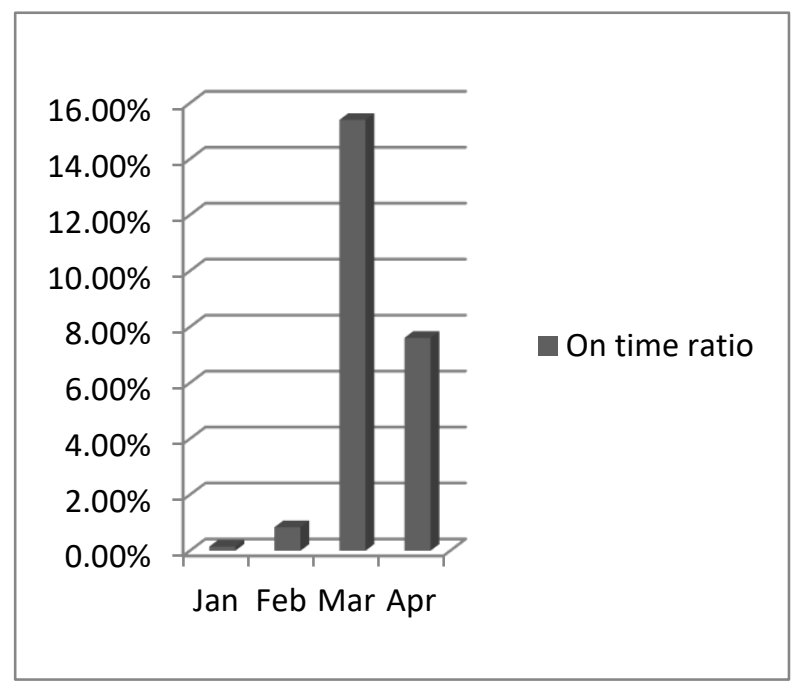

Figure 5. Sum of Enterprises Taxpayer Delivering Annual Tax Returns On Time in 2017

Source: Processed data 2018

Table 8. Sum of Enterprises Taxpayer Didn't Deliver Annual Tax Returns in 2017

\begin{tabular}{llll}
\hline Year & $\begin{array}{l}\text { Taxpayer } \\
\text { Registered }\end{array}$ & $\begin{array}{l}\text { Taxpayer } \\
\text { Didn't } \\
\text { Deliver }\end{array}$ & $\begin{array}{l}\text { Ratio } \\
(\%)\end{array}$ \\
\hline 2016 & 34,571 & $\mathbf{2 5 , 2 4 4}$ & $\mathbf{7 3 . 0 2}$ \\
Total & 34,571 & $\mathbf{2 5 , 2 4 4}$ & $\mathbf{7 3 . 0 2}$ \\
\hline
\end{tabular}

Source: Processed data 2018 
Based on the ratio analysis described above, it can be seen that the comparison of 2016 taxpayer compliance is assumed to be the year before the tax amnesty, and in 2017 after the tax amnesty, it turns out that the level of taxpayer compliance has increased. However, the percentage of increase is not too large, ie from $13.40 \%$ to $24.00 \%$. This means that only increased by only $10.60 \%$. Then regarding the comparison of the number of taxpayers who did not report or did not submit the Annual Tax Return, it decreased in 2016 by $76.92 \%$, while in 2017 it was $73.02 \%$.

This means that the tax amnesty policy is able to invite, to make taxpayers aware of their obligations to become good taxpayers, only $3.90 \%$. This test is determined from the results of the normality tests carried out and the research samples used. The samples used in different tests are interconnected and if the results of the normality test show that the sample is normally distributed, the difference test used in this study is the paramed test (Paired sample t-test). But if the sample is not normally distributed, the different test that will be used in this study is a non-parametic test (Wilcoxon Signed Rank Test).

Table 9. Normality Test

\begin{tabular}{llll}
\hline Pair & Asymp.Sig & Alpha & Information \\
\hline Before & 0.200 & 0.05 & Normal \\
After & 0.052 & 0.05 & Normal
\end{tabular}

Source : Secondary data processing 2018

The test results on the sample are said to be significant if the value of Asymptotic sig is smaller than the level of confidence used in this study, which is $5 \%$ or 0.05 . Conversely, it is said to be insignificant when the value of Asymptotic sig. greater than confidence level.The result shows that the variables or samples before and after the tax amnesty students have normally distributed data because the significance value is $>0.05$. Therefore, the next static test can be followed by a Paired Sample t-Test.

Based on table 10 above, in group statistics it is known the mean value before the tax amnesty is 681.0o with a standard deviation of 785.26 and after the tax amnesty has an average value of 1,312.50 with a standard deviation of 1,351.66.

Table 1o. Descriptive Statistics of Enterprises Taxpayer that Comply Before and After Tax Amnesty

\begin{tabular}{|c|c|c|c|c|}
\hline & \multicolumn{4}{|c|}{ Std. } \\
\hline & Mean 1 & $\mathrm{~N}$ & Dev. & SE. Mean \\
\hline Pair 1 Before & 681.00 & 8 & 785.256 & 277.630 \\
\hline After & 1312.50 & 8 & 1351.658 & 477.883 \\
\hline
\end{tabular}

It is known that the correlation value is 0.973 with a probability value (sig.) o.ooo. This shows that the correlation between before and after tax amnesty has a very real or very strong relationship, because the probability value is < 0.05

Table 11. Correlations of Enterprises Taxpayer that Comply Before and After Tax Amnesty

\begin{tabular}{|c|c|c|c|}
\hline & & Correlation & Sig. \\
\hline Pair 1 & Before \& After 8 & .973 & .000 \\
\hline
\end{tabular}

Based on table 12. regarding different tests (paired samples test) known $\mathrm{t}$ count $+/-2.904$ $>$ or $<\mathrm{t}$ table 1.895. In this case means

Using the left-hand test. The probability value is $0.02<0.05$ then $\mathrm{H}_{\mathrm{o}}$ is rejected. It can be concluded that there are differences inTaxpayer enterprises Taxpayer compliance before and after the enactment of tax amnesty. Tax amnesty is expected to have a positive impact on the world of taxation in Indonesia, 
especially to increase taxpayer compliance in Indonesia. Directorate General of Taxation issued a new policy in the form of tax amnesty with the aim of improving services to taxpayers, both enterprises taxpayers and corporate taxpayers in implementing tax obligations. One of the obligations of the taxpayers is to submit the Annual Tax Return before the due date. Tax Amnesty policy provides benefits to taxpayers who are not yet active as well as taxpayers who have not been on time to report taxes in the previous year. Tax Amnesty regulation applies 1 (one) year, ie 2016. So it is unfortunate when taxpayers who are not properly reporting tax or taxpayers not active does not take advantage of these regulations.

Table 12. Paired samples t- test

\begin{tabular}{|c|c|c|c|c|c|c|c|c|c|c|}
\hline & & \multicolumn{6}{|c|}{ Paired Differences } & & \multirow[b]{3}{*}{ df } & \multirow{3}{*}{$\begin{array}{l}\text { Sig. } \quad(2 \\
\text { tailed })\end{array}$} \\
\hline & & \multirow[b]{2}{*}{ Mean } & \multicolumn{5}{|c|}{$\begin{array}{l}95 \% \text { Confidence Interval } \\
\text { Std. Errorof the Difference }\end{array}$} & & & \\
\hline & & & Deviation & Mean & Lower & Upper & & & & \\
\hline Pair 1 & $\begin{array}{l}\text { Before- } \\
\text { After }\end{array}$ & -631.500 & 615.031 & $217 \cdot 44$ & $-1145 \cdot 678$ & $-117 \cdot 322$ & & 2.904 & 7 & .023 \\
\hline
\end{tabular}

Source : Secondary data processing 2018

The results of this study indicate that the implementation of the tax amnesty policy has succeeded in becoming a solution to increase enterprises taxpayer's compliance. The facilities provided by the Directorate General of Taxation were able to increase compliance of the enterprises taxpayers who delivered Annual Tax Returns on time.

It is proven from the results of different sample tests in pairs between before and after the enactment of Tax Amnesty. According to the Head of the Data and Information Processing Section there are some taxpayers who have paid taxes, but the taxpayers does not submit annual tax returns. Few or many taxpayers who have paid taxes and have not submitted annual tax returns will still reduce the number of enterprises taxpayer's compliance at KPP Pratama, South Jakarta. The criteria of the taxpayers are said to be obedient, namely the taxpayers that calculates, pays, and delivers the SPT on time

In Jacques's study (2010) which shows that tax amnesty partially has a positive and significant effect on the level of taxpayer compliance with a significance value less than 0.05. Junpath (2013) examined multi tax amnesty and tax compliance in South Africa. Quantitative research using this questionnaire method concluded that tax amnesty increases tax revenues and compliance in South Africa, in line with the research of Ngadiman and Huslin (2015) who examined the effect of sunset policy and tax amnesty on taxpayer compliance to get results that tax amnesty has a positive effect on taxpayer compliance. The findings of this study were also strengthened by Ida Bagus and Naniek Noviari (2017); Agus, Iwan (2016); Desak P, Ayu D, (2017); and Alberto (2016) where the results of their research using regression 
analysis stated that there was a significant influence of tax amnesty on taxpayer compliance.

\section{CONCLUSION}

The enterprises taxpayer's compliance ratio on time after the enactment of tax amnesty increased by $10.60 \%$, in 2016 amounted to $13.40 \%$ and in 2017 amounted to 24.00\%. Furthermore, the enterprises taxpayer's compliance ratio are not timely after the enactment of tax amnesty has decreased from 2016 by $9.68 \%$ to only $2.98 \%$ in 2017. The ratio of taxpayer's compliance that does not submit Annual Tax Return decreases by $3.90 \%$, namely in 2016 amounting to $76.92 \%$ to 73.02 in 2017 .

The statistical results using paired different test can be concluded that there are differences in enterprises taxpayers compliance before and after the enactment of Tax Amnesty in KPP Pratama South Jakarta. This is shown from the results of testing hypotheses using Paired Sample tTest which obtained the value of $t$ count equal to $+/-2.904$ while the $t$ table is $+/-1.895$ so Ho is rejected. This means that the Directorate General of Taxes has succeeded in increasing the compliance of enterprises taxpayers through the Tax Amnesty.

Based on the results of the research above the authors suggest: To the Directorate General of Taxes, it must be more intense to provide information to the public about the importance of reporting taxes. The most effective outreach is carried out by execution or by visiting South Jakarta residents who already have their own business, regardless of the size of the business. Furthermore, the tax amnesty program is very effective to continue to be implemented, because it is proven to provide meaningful results for the country's income.
To new Taxpayers who have registered themselves immediately given an explanation of their rights and obligations as Taxpayers, not only on $\mathrm{CD}$ or hard-copy but must be given an explanation orally. In order for taxpayers to fully understand the role of a compliant taxpayer in accordance with the tax law.

To the tax apparatus must supervise taxpayers when taxpayers begin to neglect in paying or reporting taxation, by always giving a warning to taxpayers who are late in paying or delivering Annual Tax Returns. Letters of reprimand, preferably immediately after negligent WP without having to wait for the following years.

The research and writing of this article was funded by the Ministry of Research, Technology and Higher Education DIPA: Directorate of research and community service No. Contract: 032 / KM / PNT / 2018, March 6, 2018. Under the Beginner Lecturer Research scheme. Because of this, the research team thanked profusely for being given the opportunity to develop capacity. The author also wishes to thank all parties involved, among others; to the Head of the Directorate General of Taxes, especially the Directorate General of Taxes in South Jakarta.

\section{REFERENCES}

Agus, Iwan Kesuma. (2016). "Tax Amnesty as an Effort to Optimize the Tax Function" Faculty of Economics and Business Mulawarman University Indonesia (Tax Amnesty As An Effort To Optimize Tax Functions "Faculty of Economics and Business Mulawarman University Indonesia), Journal of Financial Economics, and Management, Vol 12 ISSN 0216-7786.

Alberto. (2016). Effect of Tax Amnesty Policy by the Government on the Potential of Increasing Tax Revenue in Indonesia in 2015 (Effect of Tax Amnesty Policy by the Government on the Potential for Increasing Tax Revenue in Indonesia in 2015), the scientific journal, Bakrie University. Vol. 04 (1) 
Alm, James,. Vasquez J. Martinez \&Wallace, (2009). Do Tax Amnesties Work? The Revenue Effects of Tax Amnesties During the Transition in the Russian Federation. Journal of Economics an Policy, Volume 39, Issue 2, Pages 235-253

Aryobimo, Putut and Nur Cahyonowati. (2012). Effect of Taxpayer Perception on Fiscal Service Quality on Taxpayer Compliance with Taxpayer Financial Conditions and Risk Preference as Variable Moderating Empirical Study of Individual Taxpayers in Semarang (Effect of Taxpayer Perception on Quality Services on Taxpayer Compliance with Taxpayer Financial Conditions and Risk Preference as Moderating Variable Empirical Study of Individual Taxpayers in the City of Semarang). Dipenegoro Journal of Accounting, Vol. 1 (1), 2012, page 2.

Cahyonowati, Nur. (2011). Tax Moral and Compliance Model: Individual Taxpayer. Journal of Accounting and Indonesian Auditing, 15 (2). pp. 161-177.

Darussalam, B. Bawono, et al. (2014). Understanding Tax Non-compliance: Inside Tax Edition 26 December 2014.

Urge P, Ayu D, (2017). Implications and Evaluation of Tax Amnesty Program at Taxpayer Compliance Level in Efforts to Increase Tax Revenue in the Work Area of the Pratama Singaraja Tax Service Office (Implication and Evaluation of Tax Amnesty Program at Taxpayer Compliance Level in Efforts to Increase Tax Revenue in the Work Area of the Pratama Singaraja Tax Service Office), S1 Ak E-Journal, University of Education, Ganesha.

Directorate General of Tax. Tax revenue. http://www.pajak.go.id/penerimaan-pajak. Accessed June 8, 2017.

Gunadi. (2005). Tax accounting. Jakarta: PT Grasindo.

Handayani, Ucik, dan Nujmatul Laily. 2017. The Influence of Consciousness, Tax Penalty, and the Quality of Tax Authorities Service on Tax Compliance. Journal of Accounting and Business Education, 1 (2), hal.286-297.

http://www.pajak.go.id Tax Ratio Indonesia. Accessed on o9 June 2017.

https://id.wikipedia.org/wiki/Pengampunan_pajak. Accessed on June 10, 2017.

Minister of Finance Decree No. 192 / KMK.03 / 2007 concerning Criteria for Obedient Taxpayers.

Ida Bagus Ngurah Ari Putra Wirawan and Naniek Noviari Effects of the Implementation of Tax
Amnesty Policy and Tax Sanctions on Compliance with Individual Taxpayers (Effects of the Implementation of Tax Amnesty Policy and Tax Sanctions on Compliance of Individual Taxpayers) of the Accounting Journal of Udayana University Vol .21 (3). December (2017): 2165-2194DOI: https: //doi.org/10.24843/EJA.2017.v21.io3.p17

Jacques Malherbe. (2010). Tax Amnesties in the 2009 Landscape. In Inside Tax Issue 15 (May, XII). Darussalam: PT Dimension International Tax

Jaroslav Kovárník, Eva Hamplová, Pavel Jedlika, \& Ladislav Hájek. (2015). The Causalities of the Tax Incidence and the Modeling of Tax Processes. 2nd Global Conference On Business, Economics, Management And Tourism, 30-31 October 2014, Prague, Czech Republic, Procedia Economics And Finance 23 (2015) $1253-1259$

Junpath, Sachin. (2013). Multiple Tax Manesties and Compliance in South Africa. Durban University of Technology.

Kirchler, E., Hoelzl, E., \& Wahl, I. (2008). Enforced versus voluntary tax compliance: The "slippery slope" framework. Journal of Economic Psychology, 29(2), 210-225. doi:10.1016/j.joep.2007.05.004.

Kogler, Christoph, Matthias Kasper and Erich Kirchler. (2013). Tax Policy and the News: An Empirical Analysis of Taxpayers' Perceptions of Taxrelated Media Coverage and its Impact on Tax Compliance. University of Vienna, Austria WU - Vienna University of Economics and Business: International Taxation Research Paper Series No. 2013-07

Marcel Garz \&Verena Pagels. (2018). Cautionary tales: Celebrities, the news media, and participation in tax amnesties, Journal of Economic Behavior \& Organization, Volume 155, p. 288-300

Mardiasmo. (2014), Perpajakan. (Taxation) Revised Edition. Yogyakarta: Andi.

Muliari, N.K. and P.E. Setiawan. (2010). Effects of Perception on Tax Sanctions and Taxpayer Awareness on Compliance with Personal Taxpayer Compliance Report in Primary Tax Office (Effects of Perception on Tax Sanctions and Taxpayer Awareness on Compliance with Personal Taxpayer

Reporting at East Denpasar Primary Tax Office). Accounting and Business Journal: Faculty of Economics, Udayana University. Denpasar Timur.

Natrah Saad. (2014). Tax Knowledge, Tax Complexity and Tax Compliance: Taxpayers' View. 2nd World Conference on Business, Economics and 
Management-WCBEM 2013 Procedia - Social and Behavioral Sciences 109 (2014) p. 1069 1075

Ngadiman and D. Huslin. (2015).

Effects of Sunset Policy, Tax Amnesty, and Tax Sanctions on Tax Compliance Empirical Study at Pratama Jakarta Tax Office Kembangan, (Effects of Sunset Policy, Tax Amnesty, and Tax Sanctions on Taxpayer Compliance Empirical Study at Pratama Jakarta Tax Office Kembangan), Accounting Journal vol.12 (2), May 2015: 225-241.

Nikolaos D.Goumagias, DimitriosHristu-Varsakelis, Yannis M.Assael, (2018). Using deep Q-learning to understand the tax evasion behavior of riskaverse firms, journal Expert Systems with Applications, Volume 101, page 70.

Pinaki Bose \& Michael Jetter. (2012). Liberalization and tax amnesty in a developing economy. Journal Economic ModellingVolume 29, Issue 3, Pages 761-765.
Pranadata, I Gede Putu. 2014. Effect of Taxpayer Understanding, Quality of Tax Services, and Implementation of Tax Sanctions on Compliance with Personal Taxpayers at Batu Pranadata Primary Taxpayer. (Effect of Taxpayer Understanding, Quality of Tax Services, and Implementation of Tax Sanctions Against Compliance with Individual Taxpayers at Batu Pratama KPP. UB Thesis Journal.

Ralph-C.Bayer, Harald Oberhofer, Hannes Winner. (2015). The occurrence of tax amnesties: Theory and evidence. Journal of Public Economics, Volume 125, Pages $70-82$

Sugiono. (2010). Qualitative Research Methods. (Qualitative Research Methods) Bandung: Alfabeta.

Supadmi. (2010). Enhancing Improving Taxpayer Compliance Through Quality. Accounting and Business Journal: Faculty of Economics, Udayana University. Swistak, Artur. 2015. Tax Penalties in Tax Compliance SME. Financial Theory and Practice, 40 (1), p.129-147.

Law of the Republic of Indonesia Number 11 of 2016 concerning Tax Amnesty. 